\title{
A Preliminary survey on acarine fauna inhabiting different stored products in four districts of Malabar region, Kerala (India)
}

\author{
Sachin P James ${ }^{1 *}$, M.K. Jaisath ${ }^{1}$ and Salil K. Gupta ${ }^{2}$ \\ ${ }^{1}$ Department of Zoology, Malabar Christian College, Kozhikode Kerala, 673001 (Affiliated to University of Calicut) \\ ${ }^{2}$ Medicinal Plant research and Extension Centre, Ramakrishna Mission Ashrama, Narendrapur, Kolkata, 700103 \\ *Corresponding author: sachinponnani@yahoo.com,Tel.: +919037633327
}

Available online at: www.isroset.org

Received: 23/May/2018, Revised: 02/Jun/2018, Accepted: 19/Jun/2018, Online: 30/Jun/ 2018

\begin{abstract}
The present paper reports for the occurrence of mites on stored products in four districts of Malabar region in Kerala which includes 33 species under 14 genera 12 families and 3 orders viz, Trombidiformes (suborder Prostigmata), Mesostigmata and Sarcoptiformes (Cohort Astigmata). The Family Cheyletidae represented as the most dominating family while Cheyletus malaccensis was the most abundant species found in stored products. The representatives of Stigmaeidae and Cunaxidae families were also dominant. Among the stored product, from pepper maximum number of mite species were identified followed by boiled rice and raw rice. Coriander represented with six species of mites whereas wheat represented with five species. This study also reported 3 species namely Lasioseius sp.1, Stigmaeus sp1 and Tydeus sp.1 which appeared to be un described and among these one species Lasioseius sp.1 which is being reported here for the first time from India inhabiting stored products.
\end{abstract}

Keywords: Mite, Stored products, arthropoda, Malabar, Kerala.

\section{INTRODUCTION}

From the early stages of human civilization, people are aware of the importance of food materials to be stored and different methods of storing and preservation techniques have been practiced. The mites comprise a large group of Phylum Arthropoda and belong to subclass Acari under class Arachnida. These are microscopic in size, well distributed in all types of habitats throughout the world. The stored grain and stored products mites infest and damage cereals and other food stuffs as cheese, flour, seed, bulbs, tubers and dried fruits of all kinds. The mites cause direct and indirect damage to stored grains and their products by feeding on the grains and making those unsuitable for human consumption besides raising their moisture contents, generating sufficient heat for the growth of infectious bacteria and fungi. Apart from that, they also cause depletion of protein, amino acids, carbohydrate and vitamin contents of grains [1,2]. Over and above many of the mites which occur in stored product cause itching, inflammation, dermatitis, etc. to those persons who handle the grains. Though a good amount of work on mites occurring on stored products have been done during the last two decades, but most of those are from northern India like Punjab and Haryana and from Karnataka in southern India. As far as Kerala is concerned, the stored products mites have not been explored and therefore the available knowledge is meager. Keeping all these in view, The present research topic was chosen to explore during April 2015 to March 2016 both the damage causing and predatory mites from some selected stored products and the results thereof are presented in this paper. This work was carried out in collaboration between all authors. Author Sachin P James designed the study, wrote the protocol, performed the study and wrote the final draft of the manuscript, author M.K. Jaisath managed the analyses, literature searches, author Salil K Gupta performed the statistical analysis and wrote the first draft of the manuscript. All authors read and approved the final manuscript.

\section{RELATED WORK}

Since no earlier studies are available from the targeted area on stored product mites the present results could not be compared with those of the earlier ones.

\section{MATERIALS AND METHODS}

The samples of stored products like cereals (Rice both boiled and raw, Wheat), Spices (Coriander, Pepper), Medicinal plant parts (Jamun, Muthanga) etc. were collected from the different places comes under the jurisdiction of four Districts in the Malabar region as listed below and the names given in the parenthesis were the places from where the samples were collected.

1. Wayanad (Kalapatta \& Manandavady)

2. Kannur (Talassery, Payyannur)

3. Kozhikode District (Calicut City \& Payyoli),

4. Malappuram District (Kuttipuram, Ponnani \& Malappuram)

Uy

Stored products thus collected were taken in clean polyethylene bags with proper labelling and initially screened in the laboratory under a Magnus stereo zoom binocular microscope. These were subjected to heat desiccation method through modified Tullgren's 
apparatus for extraction of mites in a receiver containing $70 \%$ alcohol fitted with the stem of the funnel. The collected mites were sorted out in different groups and were mounted in Hoyer's medium for identification. The identification was done by consulting the updated literature and with the help of by the third author (S.K.Gupta). The identified mite species have been documented with their habitat, locality, relative abundance and importance if any.

\section{RESULT AND DISCUSSION}

The materials collected from different stored products and identified list of mites have been provided in Table 1. Identified species of mites revealed the occurrence of total of 33 species of mites which belonged to 14 genera, and 12 families and 3 orders. The representative of the Prostigmata appeared to be most diverse because it included 18 species under six genera and four families, followed by Mesostigmata represented by ten species under six families under six genera and least diverse group was Astigmata represented by 5 species under 2 genera and 2 families (Table.1).

Among the mite species, those belonging to Ascidae under Mesostigmata and Cunaxidae, Stigmaeidae, aphignathidae and Cheyletidae under Prostigmata were of predatory in nature and mostly feeding upon the Acarid mites. The species under Uropodidae were fungal feeders and on the contrary the species belonging to Acaridae under Astigmata were the damage causing mites of the stored products.

It also appeared that the species which were found to be the most dominant belonged to Cheyletus malaccensis, C.eruditus and C.fortis, under Chelytidae. The representatives of Stigmaeidae and Cunaxidae families were also dominant. Among the stored product, pepper appeared to be inhabiting maximum number of mite species ( 9 species) followed by boiled rice and raw rice ( 8 and 7 species each respectively). Coriander represented with 6 species and in wheat five species were identified. Contrary to this jamun, inhabited two mite species and rest of the stored products had only one species.

Lasioseius sp.1, Stigmaeus sp1 as well as Tydeus sp.1 were appeared to be new to science and thus are under further study for confirmation of novelty. Among the mites, Cheylectus malaccensis, Tyrophagus putrescentiae and Austroglycyphagus geniculatus could be collected on as many as three types of stored products, while C.eruditus could be collected on two of stored products.

\section{CONCLUSION AND FUTURE SCOPE}

Since no earlier studies are available from the targeted area on stored product mites the present results could not be compared with those of the earlier ones $[3,4,1,5]$ who contributed on the stored product mites of India and Gupta 2012 [2] who provided summarized information on this aspect. From the preliminary results obtained from the present study, enough indication is provided indicating that the stored products mites of Kerala are quite rich and more thorough investigation is needed to add further knowledge in this area of research.

\section{ACKNOWLEDGMENT}

The first author is thankful to UGC for the financial support sanctioned as minor research Project with which the present study was carried out. The authors are thankful to DST-FIST (2014) for providing financial support to adequately equip the laboratory used in present study and without those the present work could not be carried out successfully. Thanks are also to The Principal Malabar Christian College, Calicut for providing the infrastructure facility and encouragement.

\section{REFERENCES}

[1] N. Nangia, Studies on mites associated with stored products, bioecology and evaluation, different methods of control acarids (Astigmata: Acaridae), Ph.D. Thesis Uni, Agri,Sci,. Bangalore, $253 \mathrm{p}, 1986$.

[2] S.K Gupta, Handbook.Injurious and beneficial mites infesting agricultural crops in India and their management. Nature books India, New Delhi, 362.pp.,2012

[3] G.K. Girish, .K. Goel and K.Krishnamurthy, Occurrence of Acaropsis docta Berlese (Prostigmata: Cheyletidae) on Trogoderma granarium Fab., At Hapur (U.P.) Bulletin grain Tech.9:83-85, 1971.

[4] R.B. Mathur and S.Mathur, Mites associated with stored grain/ products in Haryana, India, Indian J. Acar., 7:4-52., 1983.

[5] A. Gupta and M. Chatterjee,. Some new records of mites infesting stored grains in Kolkata and its neighbourhood. Rec.Zool.Survey.India. 102:77-82, 2004. 
Table 1. List of mites different stred products

\begin{tabular}{|c|c|c|c|c|}
\hline Order/Family/Species & Habitat & Locality & Relative abundance & Remarks \\
\hline \multicolumn{5}{|c|}{ Trombidiformes } \\
\hline \multicolumn{5}{|l|}{ Family: Cheyletidae } \\
\hline Cheyletus eruditus & Rice (boiled), Jamun & Talassery,Calicut & 5 & Predatory in nature \\
\hline Cheyletus fortis & Rice (raw) & Calicut & 3 & Predatory in nature \\
\hline Cheyletus malaccensis & Rice (raw) Pepper, Jamun & Calicut, Kalapetta, Thalassery & 7 & Predatory in nature \\
\hline Cheyletus sp. 1 & Pepper & Calicut & 1 & \\
\hline Cheyletus sp.2 & Wheat & Calicut & 1 & Predatory in nature \\
\hline Cheyletus sp.3 & Pepper & Malappuram & 1 & Predatory in nature \\
\hline Bothrocheyla sp. & Pepper & Calicut & 1 & \\
\hline \multicolumn{5}{|l|}{ Fam: Cunaxidae } \\
\hline Cunaxa evansi & Rice (boiled) & Payyoli & 1 & Predatory in nature \\
\hline Cunaxa sp.1 & Coriander & Payyoli & 1 & Predatory in nature \\
\hline Cunaxa sp.2 & Pepper & Ponnani & 1 & Predatory in nature \\
\hline \multicolumn{5}{|l|}{ Fam: Stigmaeidae } \\
\hline Agistemus sp. & Rice raw & Calicut & 1 & \\
\hline Stigmaeus sp.1 & Rice boiled & Calicut & 1 & Appears to be undescribed \\
\hline Stigmaeus sp.2 & Rice boiled & Calicut & 1 & Predatory in nature \\
\hline Stigmaeus sp.3 & Rice raw & Payyoli & 1 & Predatory in nature \\
\hline Stigmaeus sp four & Coriander & Kuttipuram & 1 & Predatory in nature \\
\hline Stigmaeus sp.5 & Coriander & Thalassery & 1 & Predatory in nature \\
\hline \multicolumn{5}{|l|}{ Fam: Raphignathidae } \\
\hline Raphignathus sp.1 & Rice raw & Malappuram & 1 & \\
\hline Rahhignathus sp.2 & Pepper & Ponnani & 1 & \\
\hline \multicolumn{5}{|c|}{ Mesostigmata } \\
\hline \multicolumn{5}{|l|}{ Fam: Tydeidae } \\
\hline Tydeius sp.1 & Muthunga & Calicut & 1 & Appears to be undescribed \\
\hline Tydeius sp.2 & Wheat & Ponnani & 1 & \\
\hline \multicolumn{5}{|l|}{ Fam: Ameroseiidae } \\
\hline Kleemania plumosus & Rice raw & Payyoli & 1 & \\
\hline Kleemania sp.1 & Pepper & Talassery & 1 & \\
\hline Kleemania sp.2 & Pepper & Calicut & 1 & \\
\hline \multicolumn{5}{|l|}{ Fam: Attisoeiidae } \\
\hline Lasioseius ometus & Rice boiled & Calicut & 1 & \\
\hline Lasioseius sp.1 & Coriander & Calicut & 1 & Appears to be undescribed \\
\hline \multicolumn{5}{|l|}{ Fam: Glycyphagidae } \\
\hline Autroglycephagus geniculatus & Rice boiled, Coriander, Pepper & $\begin{array}{l}\text { Calicut, } \\
\text { Kalapetta, Payyoli }\end{array}$ & 3 & \\
\hline \multicolumn{5}{|l|}{ Fam: Pyroglyphidae } \\
\hline Euroglyphus maynei & Wheat & Ponnani & 1 & \\
\hline \multicolumn{5}{|l|}{ Fam: Uropodidae } \\
\hline Uropoda sp. & Rice boiled & $\begin{array}{r}\text { Payyoli } \\
\end{array}$ & 1 & Fungal Feeder \\
\hline \multicolumn{5}{|c|}{ Sarcoptiformes } \\
\hline \multicolumn{5}{|l|}{ Fam: Acaridae } \\
\hline Tyrophagus putrescentiae & Rice boiled, Rice raw, Coriander & Calicut & 3 & \\
\hline Tyrophagus sp.l & Dust & Calicut & 1 & \\
\hline Tyrophagus sp.2 & Wheat & Calicut & 1 & \\
\hline \multicolumn{5}{|l|}{ Fam: Saproglyphidae } \\
\hline Suidasiidae nesbitti & Wheat & Malappuram & 1 & \\
\hline Suidasisidae sp.1 & Rice & Calicut & 1 & \\
\hline
\end{tabular}

